\title{
Factors Influencing Students Motivation to Learn in Bahauddin Zakariya University, Multan (Pakistan)
}

\author{
Muhammad Imdad Ullah \\ MS Management Science, Shaheed Zulfikar Ali Bhutto Institute of Science and Technology, \\ Islamabad (Pakistan) \\ E-mail: Imdadbzu@gmail.com
}

\begin{abstract}
Aamir Sagheer
M.Phil Scholar, Department of Sociology, Bahauddin Zakariya University, Multan (Pakistan) E-mail: sagheer.aamir@gmail.com

Tehmina Sattar

Lecturer, Department of Sociology, Bahauddin Zakariya University, Multan

E-mail: sattar.tehmina@gmail.com

E-mail: tehminasattar@bzu.edu.pk
\end{abstract}

\section{Shahbaz Khan}

MS Management Science, Shaheed Zulfikar Ali Bhutto Institute of Science and Technology, Islamabad (Pakistan)

Accepted: June 16, 2013 Published: August 17, 2013

Doi:10.5296/ijhrs.v3i2.4135

URL: http://dx.doi.org/10.5296/ijhrs.v3i2.4135

\begin{abstract}
:
Motivation is the paramount medium and obligatory precondition that provoke critical thinking among the students. The major premise of this research is to reveal diverse factors that can lower the motivation of the students to acquire good academic grades. Cross sectional survey research design was used by the researcher to accumulate the data from $N=300$ respondents through multistage sampling technique. Questionnaire was used as a tool for the rationale of data collection from Social Science departments of Bahauddin Zakariya University, Multan (Pakistan). Descriptive Statistics, Correlation method, Analysis of Variance and Reliability Coefficients were used by the researcher to appraise the relationship among the study variables. From the analysis it was found that usage of effectual teaching methodologies, adequate learning environment in the classroom and self-motivated involvement of the students to slot in knowledge acquisition are the foremost determinants that can increase the students motivation for learning process. From the analysis the researcher concluded that encouraging the constructive classroom environment by inducing discussion, establishment of cooperative learning environment and small group work can amplify the students motivational level for the purpose of engaging in the learning process. In addition to this inconsistent workload on the students, usage of obsolete teaching
\end{abstract}


methodologies, large class size, peer pressure to resist the learning process and teachers biased behavior with the students are the foremost factors that can diminish the students interest in their studies. Usage of modern instructional practices, provision of adequate classroom environment and encouragement of analytical feedback from the students are the foremost remedies that can increase the motivational level among the students to acquire premium academic grades.

\section{Introduction:}

Motivation to learn is the involvement and commitment of the student to learn and acquire eminence academic grades that can facilitate them in their future occupational carrier (Gottfried, et al. 2001; Murdok and Miller, 2008). Motivation is mainly of two types that can be related with the academic achievement of the students. These two types of motivations are characterized by extrinsic and intrinsic motivations. Intrinsic motivation is narrated to the inner abilities of the students to interact with their environment in order to achieve their required and predetermined goals. Conversely extrinsic motivation refers to the fact that people are motivated towards the external sources through assorted kinds of rewards and grades (Tanveer, et al. 2012).

Motivation is the concept that elucidates the direction, persistence and goal directed behavior of a person. Students motivation is the key parameter for their success and achievement of high-quality academic grades. Student motivation depends upon their subjective experiences and willingness to engage in conceptualization of lessons. Learning refers to information processing or knowledge acquisition when a person is acquiring knowledge (Thrash and Elliot, 2001) while performance refers to the manifestation of knowledge and skills after it has been acquired at the utmost level but it also depends upon the nature of the tasks given to the students by their teachers. There are two foremost subjective reactions of the students towards an academic task engagement. Firstly when the student anticipates some sort of fear or failure then they feel apathy, embarrassment and sense of disappointment. Secondly when they expect some success from their academic tasks then they feel happiness, craftsmanship and flourishing performance (Wigfield and Eccler, 2000). Motivation can be created in classroom, home or at the level of school administration. Students must have strong motivation to acquire knowledge. If the teacher has passable leadership qualities then students are more motivated towards learning process. Instructional practices can enhance the motivational level and academic achievement among the students (Condry, 1987).

Students motivation is the essential element for quality teaching and learning process. There are five key constituents that have momentous impacts on students motivation to learn. These factors are teachers interaction with their students, class environment and class size. Thus a teacher must be trained, dedicated and responsive to educate their children (Whiting, et al. 2008). On the other hand the curriculum content should be passable and relevant towards the present day needs. But on the other hand individual disparities among the students can influence their motivational level with respect to time management, educational background and learning proficiencies etc (Dean and Dagostino, 2007). Teachers can play a vital role in increasing the motivation among the students by the subsequent techniques that 
encompass: (1) Usage of inventive teaching methodologies (2) Devotion of teachers towards their students (3) Creation of passionate learning environment for the classroom and (4) Promotion of practical work experience (Quinn and Eckerson, 2010; Sutherland, 2005). Teachers behavior is strongly related with academic achievement of students by creating, enhancing, flourishing and establishing their level of motivation. Motivation is not the stagnant phenomenon but it plays an imperative role for the students to achieve their predetermined goals through cognitive restructuring and adequate decision making power. Motivation not only compels a student to do diverse academic activities but it is also allied with command on subject, enhancing personal responsibility and achievement of deep conceptualization for the students (Bridges, 1990; Theobald, 2006).

When learning becomes compulsion for the students rather than passion then their grades began to fall. Thus academic performance of the student is directly linked with their motivation to learn. But motivation of the students towards the process of learning can be improved when the teacher uses the effectual teaching strategies on the students (Afzal, et al. 2004; Murphy, 2004). The factors that influence the students motivation towards their learning process includes assorted environmental factors such as classroom cleanliness, teachers behavior with the students and interest level of the students towards a particular course content (Johnson, 2008). The incentives given to the students are indispensable in increasing their level of motivation. Tangible and non-tangible incentives given by the teachers and parents are also worth mentioning factors that have an indispensable influence on the students motivation level (Ali, et al. 2011). Tangible rewards include monetary rewards and certificates of academic achievement while the non-tangible rewards include acknowledgement and hard work of the students. Students are less willing to excel in the future due to lack of incentives and low motivation level of the students (Dickinson and Balleine, 2002). Teachers can play an indispensable role in increasing the motivation among the students. These factors include the students active participation in the process of learning through discussion, students engagement in learning activities and current educational needs of the students (Wiseman and Hunt, 2001; Sattar, 2012). Despite these factors other responsible parameters that have an imperative influence on increasing the motivation level of the students include classroom environment, class size, confidence level of the students, teachers behavior and norms of the school. Students can learn more precisely in the classroom environment that comprises of affection, coordination and participation etc (Tanveer, et al. 2012, Theobald, 2006).

Learning process may be student centered or teacher centered. Teacher centered approaches are more universal and practical in most of the educational institutions. These approaches are referred to direct instruction/ deductive teaching in which the teacher discussed the lecture with the students (Eley, 2006; Nilsen, 2009). On the other hand learner centered approaches are also called inductive methods or discovery learning in which the cooperative learning methodology is present. Students should be motivated to engage in the process of learning. When learners are engaged in higher order thinking then they will be required to generalize, construct, hypothesize and interpret knowledge. Teachers must use the modern teaching methodologies for delivering lectures to the students whether the learning process may be student centered or teacher centered. These methodological areas include 
discussion method, small group work and cooperative learning method. Discussion is the modern and effective teaching methodology in which the students and the teachers are in the face to face interaction in order to exchange their ideas. The major purpose of discussion is to enhance the knowledge of the learner about the particular subject (Dillon, 1994). Thus discussion is the effective teaching methodology that can increase the students motivation towards knowledge acquisition. In discussion the students are motivated towards the process of learning because the major focus is to reach an informed and rational consensus in which every opinion is given value. As a result the students feel a sense of achievement (Brookfield, 1990, Dart, 1994). On the other hand in group work two or more students work together without the help of the teacher (at least for some point of time). In group work the students are motivated to work because students become the passive recipients of knowledge that can enhance the achievement and retention. In addition to this group work increases the communication skills and prior knowledge of the student about the particular subject (Killen, 2003; Winkel, 1999). Despite this cooperative learning means working together to achieve shared goals in the form of small group. The major concept of cooperative learning is that learner cannot achieve the common goal by working together therefore cooperative learning helps the group members to acquire the process of knowledge acquisition (Boo, et al. 2001; Wong and Wong, 1998).

\section{Rationale of study:}

Learning often becomes associated with hard work instead of delight. Numerous students are physically present in the classroom but they are mentally absent and therefore their learning experience becomes filled with negligence and flaws. Awareness about students motivational factors for learning can assist the teachers for increasing the students motivation to learn. In addition to this the optimistic attitudes and values of students are also indispensable in plummeting their lack of interest in their studies. The foremost objectives of this research were to emphasize the factors that persuade the students motivation for learning. Hence the researcher addressed the subsequent research objectives for the present studies:

1. What is the importance of students motivation in their learning process?

2. How classroom climate motivate the students to learn in an adequate way?

3. What are the major motivational factors (associated with teachers) that can help the students to learn and acquire good grades?

4. What are the effective teaching methodologies that should be implemented by the teachers that can motivate the students to learn in a passable way? To what extent the teachers can increase the motivational level among the students by using modern teaching methodologies?

5. What are the major recommendations that can assist the students to slot in the process of learning?

\section{Research Methodology:}

Student motivation is naturally associated with students aspiration to contribute in the learning process. But it also concerns the rationales that underlie their level of involvement in the process of learning. Students may be uniformly motivated to accomplish an assignment but the motivational factors behind those students differ according to the situation and skills 
of the students. Consequently the researcher applied adequate research methodology for the present study. The major intention of this research was to explore the factors that have an influence upon the motivation level of the students therefore data was collected from Bahauddin Zakariya University, Multan (as universe). As the data was collected at one point of time therefore the researcher opted cross sectional survey research design for the present study. All the students of BZU that were enrolled in Social Science departments according to the reference letter no. BS (Edu.)-14(25)/96/2065/dated 19-4-2012 with respect to admission completion on date 31-3-2012 were the target population. The most momentous intention of this research was to ensure the validation of the facts, accumulation of the facts and analyzing the causal relationship among the study variables therefore the researcher used quantitative research design for the present study. Afterward the researcher applied Multistage sampling technique on the respondents that were targeted for the underlying principle of data collection. The researcher selected 5 departments out of 9 departments of Social Sciences through simple random sampling technique in the first stage of sample selection. Afterward the researcher selected the students from required departments for the rationale of data collection. On average 50-65 students were opted depending upon the size of the class through simple random sampling technique in second stage of sample selection. Subsequently the researcher interviewed the selected respondents through questionnaire. Both open and close ended questions were added by the researcher to evaluate the predetermined and exploratory response of the respondents. Hence a total of 312 respondents were selected for the purpose of response evaluation but due to content error about 12 questionnaires were not passably filled by the respondents therefore the researcher evade those questionnaires so that an adequate depiction of the responses can be done. Afterward the researcher put the data in SPSS software (version 17) to find out the causal analysis among the study variables. Descriptive Analysis, Correlation method, One way ANOVA and Reliability test were applied by the researcher to ensure the validity of the hypothesis.

\section{Results and discussion:}

\subsection{Table to demonstrate the factors that influence the students motivation to learn:}

\begin{tabular}{|l|l|l|l|l|l|}
\hline Statements & $\begin{array}{l}\text { Strongly } \\
\text { agree }\end{array}$ & Agree & Neutral & Disagree & $\begin{array}{l}\text { Strongly } \\
\text { disagree }\end{array}$ \\
\hline \multicolumn{3}{|l|}{ Factors related with classroom environment that can increase the motivation of the students to learn. } \\
\hline $\begin{array}{l}\text { Class size affects students motivation to learn. } \\
\text { Peer pressure to resist studying affects students } \\
\text { motivation to engage in the process of learning. }\end{array}$ & $16.7 \%$ & $44 \%$ & $24 \%$ & $13.3 \%$ & $2 \%$ \\
\hline
\end{tabular}




\begin{tabular}{|l|l|l|l|l|l|}
\hline \hline $\begin{array}{l}\text { Positive classroom climate helps the students in } \\
\text { understanding the content of the lecture being } \\
\text { communicated. }\end{array}$ & $28.2 \%$ & $54.5 \%$ & $8 \%$ & $4 \%$ & $5.3 \%$ \\
\hline $\begin{array}{l}\text { Excessive mobile phone usage in classroom reduces } \\
\text { students concentration on their studies. }\end{array}$ & $26 \%$ & $43.3 \%$ & $12.7 \%$ & $8 \%$ & $10 \%$ \\
\hline $\begin{array}{l}\text { Positive competition among students can enhance the } \\
\text { students motivation to learn. }\end{array}$ & $42.5 \%$ & $36 \%$ & $11.5 \%$ & $6 \%$ & $4 \%$ \\
\hline
\end{tabular}

Factors related with teachers behavior that can increase the motivation of the students to learn.

\begin{tabular}{|l|l|l|l|l|l|}
\hline $\begin{array}{l}\text { Teachers biased behavior is the major factor that } \\
\text { diminishes the students motivation for learning. }\end{array}$ & $55 \%$ & $20 \%$ & $11 \%$ & $9 \%$ & $5 \%$ \\
\hline $\begin{array}{l}\text { The role of teacher as a facilitator during class } \\
\text { discussions is the major motivator for students } \\
\text { learning. }\end{array}$ & $30 \%$ & $50 \%$ & $13.3 \%$ & $4 \%$ & $2.7 \%$ \\
\hline $\begin{array}{l}\text { Teachers focus on students feedback is the major } \\
\text { motivator for the students to learn. }\end{array}$ & $26 \%$ & $40 \%$ & $17.3 \%$ & $14 \%$ & $2.7 \%$ \\
\hline $\begin{array}{l}\text { Non-verbal encouragement (e.g. maintaining eye } \\
\text { contact) during the lectures is the major motivator for } \\
\text { the students to learn. }\end{array}$ & $27.1 \%$ & $43.6 \%$ & $14 \%$ & $13.3 \%$ & $2 \%$ \\
\hline $\begin{array}{l}\text { Teachers positive behavior is the major motivator for } \\
\text { the students to learn. }\end{array}$ & $46 \%$ & $33.3 \%$ & $7.3 \%$ & $10.7 \%$ & $2.7 \%$ \\
\hline
\end{tabular}

Factors related with teaching methodologies that can increase the motivation of the students to learn.

\begin{tabular}{|l|l|l|l|l|l|}
\hline $\begin{array}{l}\text { Using discussion method is the effective teaching } \\
\text { methodology that can augment the motivation of the } \\
\text { students to learn.. }\end{array}$ & $52 \%$ & $32 \%$ & $9.3 \%$ & $4.7 \%$ & $2 \%$ \\
\hline $\begin{array}{l}\text { Using small group work is the modern teaching } \\
\text { methodology that can increase the motivational level of } \\
\text { the students to learn. }\end{array}$ & $48 \%$ & $28 \%$ & $10 \%$ & $4 \%$ & $10 \%$ \\
\hline
\end{tabular}




\begin{tabular}{|l|l|l|l|l|l|}
\hline \hline $\begin{array}{l}\text { Provision of relative reading material can increase the } \\
\text { students motivation to learn. }\end{array}$ & $42 \%$ & $30 \%$ & $21.3 \%$ & $4 \%$ & $2.7 \%$ \\
\hline $\begin{array}{l}\text { Cooperative learning is the modern teaching } \\
\text { methodology that can increase the motivational level of } \\
\text { the students. }\end{array}$ & $40 \%$ & $25 \%$ & $14.1 \%$ & $15.3 \%$ & $5.6 \%$ \\
\hline \begin{tabular}{l} 
Factors related with students motivation to learn by themselves. \\
\hline $\begin{array}{l}\text { Active involvement of the students motivated them to } \\
\text { learn. }\end{array}$
\end{tabular} 38.7\% & $32.6 \%$ & $12 \%$ & $10.7 \%$ & $6 \%$ \\
\hline $\begin{array}{l}\text { Positive reinforcement by the teachers motivates the } \\
\text { students to learn for acquiring good academic grades. }\end{array}$ & $28.7 \%$ & $54 \%$ & $10.7 \%$ & $5.3 \%$ & $1.3 \%$ \\
\hline $\begin{array}{l}\text { Excessive workload on students reduces their } \\
\text { motivation to learn deeply. }\end{array}$ & $36 \%$ & $34 \%$ & $23.3 \%$ & $2.7 \%$ & $4 \%$ \\
\hline $\begin{array}{l}\text { Internal motivation of the students is more long lasting } \\
\text { and more self directive tool to enhance the students } \\
\text { motivation to learn. }\end{array}$ & $36 \%$ & $43.3 \%$ & $12 \%$ & $6 \%$ & $2.7 \%$ \\
\hline \begin{tabular}{l} 
motivator for the students to learn. \\
\hline
\end{tabular} & $47.9 \%$ & $32 \%$ & $12.7 \%$ & $4 \%$ & $3.4 \%$ \\
\hline
\end{tabular}

\section{Discussion of Table No. 4.1:}

Motivation is primarily the attribute that compel us to do or not to do something (Broussard and Garrison, 2004). Thus there are many factors that motivate the students to learn. These factors comprised of various cognitive abilities of the students, creativity, motivational level, maintenance factors and group work (Higbee, 1996). There are mainly three types of motivations: Intrinsic motivation, extrinsic motivation and motivation to learn. In intrinsic motivation students participate in learning process in order to seek pleasure from internal emotions while in extrinsic motivation they participate in the learning process to receive external incentives and in motivation to learn the students participate in the academic activities only for their future (Higbee, 1996). Motivation is the best medium that engages the person in higher order thinking and developing analytical insight in students. The above mentioned table reveals the factors that influence students motivation for learning. These factors comprise of diverse factors related with classroom environment, teachers behavior, usage of effective and modern teaching methodologies as well as students own motivation for learning. It is evident from table no. 1 that classroom size is the foremost factor that has 
strong influence on the students inspiration for their process of learning. When classroom size is outsized then it becomes impossible for the teacher to give direct instruction with adequate attention to every student. Thus $28 \%$ respondents strongly agreed and $34 \%$ agreed that classroom size is the major factor that has an impact on the students motivation towards their learning process. On the other hand $18.7 \%$ respondents gave a neutral response on this stance. Over and above this $14 \%$ respondents disagreed and $5.3 \%$ strongly disagreed that classroom size is the strong factor behind student motivation towards their learning process. These respondents argued that if the teacher has strong knowledge and convincing competence then class size is not the issue indeed. The other factor that has strong influence on the students motivation towards learning process is peer group. If the peer group is motivated towards good grade attainment then it will have the positive influence on the students academic achievement. On the other hand if the peer group is opposed towards learning and cognitive process then student becomes demotivated towards learning process. The above cited table supports this conclusion because $16.7 \%$ respondents gave a strongly agreed response and $44 \%$ respondents gave an agreed response on this stance. On the other hand a minor percentage of the respondents disagreed on this proposition (13.3\% disagreed and $2 \%$ strongly disagreed).

The other factor that has strong influence on the students motivation towards their learning process is positive classroom environment that helps in understanding the content of the knowledge. Students, teachers as well as school administration can create a positive classroom environment by various instruction patterns that augment their creativity and cognitive abilities. Thus the above mentioned table depicts that $28.2 \%$ respondents strongly agreed and $54.5 \%$ agreed that constructive classroom environment is the major factor that motivates the students towards their leaning process and also facilitates them to acquire good grades. On the other hand $8 \%$ respondents gave neutral response on this stance. While some respondents (4\% disagreed and 5.3\% strongly disagreed) denied this stance. Table no. 1 also demonstrates that excessive mobile phone usage is the foremost factor that diverts the concentration of the students from lecture and they get inadequate conceptualization upon the particular stance delivered by the instructor. Accordingly $26 \%$ respondents strongly agreed and $43.3 \%$ respondents agreed on this stance. On the other hand $12.7 \%$ respondents gave a neutral response on this stance. Competition is the positive factor that has strong influence on the students academic activities. When competition is at its peak then students are more motivated towards the process of learning (Atta and Jamil, 2012). But if the competition is converted into conflict then the learning process of the students becomes restricted. Hence $42.5 \%$ respondents strongly agreed and $36 \%$ respondents agreed that competition among the students have the positive impact on students motivation towards their learning process. On the other hand $10 \%$ respondents denied this stance $(6 \%$ disagreed and $4 \%$ strongly disagreed).

The above mentioned table also demonstrated various factors that are related with the teachers and that have strong influence on the students motivation towards their learning process. In general terms it is also known as teachers favoritism. When teachers admire someone's attitude then they give more marks to those students despite their appalling performance in exams. On the other hand the personality, convincing power and 
communication styles can make a teacher biased towards a student. In this way some students get extra benefits from the teachers and the other students becomes deprived from these advantages. Thus 55\% respondents strongly agreed and $20 \%$ agreed on this stance. On the other hand $11 \%$ respondents gave a neutral response on this issue. In addition to this a minority of the respondents (9\% disagreed and 5\% strongly disagreed) on this stance. Teachers must enhance the motivation among the students by emphasizing on their learning goals (Gottfried, et al. 2001).

Motivation is the aspiration of the person to engage in certain activity to achieve a desired goal. Motivation is actually the driving force that focuses on achieving the predetermined goals through a certain line of action. The other factor that can motivate the students towards learning process is the teacher's role as a catalyst/facilitator during class discussions (Bielaczyc, 2003; Evertson, et al. 2000). Sometimes the teachers encourage discussion but they abolish their role as a facilitator so that students can learn in an appropriate way. When teachers become more enthusiastic towards class discussion then students can learn in an appropriate way. Thus $80 \%$ respondents agreed on this stance $(30 \%$ strongly agreed and 50\% agreed). On the other hand $13.3 \%$ respondents gave a neutral response on this standpoint. In addition to this $4 \%$ respondents disagreed and $2.7 \%$ strongly disagreed on this viewpoint. If teacher encourage the students response then the students become motivated towards learning but if the students receive bad commends and off-putting gestures from the teachers then they will diminish their feedback towards discussion or content of knowledge. Thus $26 \%$ respondents strongly agreed and $40 \%$ agreed that students feedback is the major factor that can encourage them in learning process. On the other hand $17.3 \%$ respondents gave a neutral response on this stance. On the other hand 14\% respondents disagreed on this issue. Extrinsic rewards are very important for the students motivation to learn. When teachers verbally appreciate the students then this will have optimistic impact on their learning process but on the other hand many gestures can also motivate the students learning process. These gestures comprise of appreciation and encouragement gestures (Deci, et al. 1999).

Teachers must be fully committed to their lectures and communication. Communication must be comprised of verbal as well as non-verbal communication. Non-verbal communication attracts the attention of the students towards their process of learning. Thus $27.1 \%$ respondents strongly agreed and $43.6 \%$ agreed on this stance while the disagreed percentage of the respondents was $15.3 \%$. Teachers affirmative behavior is the major motivator for the students to learn and conceptualize their lessons in an adequate way. When teacher becomes biased and develop negative attitude towards students then the students become less motivated towards their process of learning. The table thus illustrates that $46 \%$ respondents strongly agreed and $33.3 \%$ agreed that teachers positive behavior is the major motivator for the students to learn in an adequate learning atmosphere. On the other hand $10.7 \%$ respondents disagreed on this stance. Although the most indispensable factors that are related with the students motivation comprise of their self directive attitude towards the process of learning. But on the other hand the major thing that can augment the motivation level of the students is their instructional activities. These instructional activities must comprise of the cooperative and collaborative learning methods (Hidi and 
Haraackiewicz, 2000; Stipek, 1996).

The above mentioned table also depicts the major factors that are related with teaching methodologies. These methods have strong and direct influence upon the students learning behavior. These methods comprise of discussion methods, small group work, provision of relative reading material and cooperative learning. The first method that provokes the students motivation to learn is usage of discussion method that assist the students to conceptualize the full content of the lesson. The table shows that discussion is the effectual teaching methodology that motivates the students to learn. Thus 52\% respondents strongly agreed on this stance and $32 \%$ respondents just give an agreeable statement. In addition to this $9.3 \%$ respondents gave a neutral response on this stance while $6.7 \%$ respondents denied this statement. Sometimes the teachers use ineffective teaching methodologies that lower the motivation level of the students. These obsolete teaching methodologies comprise of repetition, individual work and memorization etc (Nye, 2004). But the researcher argues that usage of cooperative learning, group work and discussion are the major techniques that motivates the students towards an effective learning process. Over and above $48 \%$ respondents strongly agreed that group work is the modern and effective teaching methodology that can motivates the students to learn. Group work is given more importance because those groups comprise of high and low ability students. In this way low ability students can learn from other students. Due to this cooperation not only motivation level but also academic grades of all the students increases (Deci, et al. 1999; Young, 1977). Conversely $40 \%$ respondents strongly agreed that cooperative learning is the major teaching methodology that should be adopted by the students. In addition to this provision of relative reading material can increase the students motivation to learn. Hence $42 \%$ respondents agreed on this stance. In addition to this some respondents gave a neutral response $(10 \%$ respondents on group work, $14.1 \%$ respondents on cooperative learning and $21.3 \%$ respondents on provision of relative learning material) on declaring teaching methodologies as an imperative factor for the students motivation to learn. On the other hand $20.9 \%$ respondents disagreed that cooperative learning is the major teaching methodology that have direct influence on the students motivation to learn. Despite this $6.7 \%$ respondents disagreed that provision of relative learning material is the best method that can increase the students motivation and their interest in the learning process. On the other hand $14 \%$ respondents denied the stance that usage of small group work for the students can increase their interest and conceptualization towards their studies.

The behavior of the teacher in a class can increase or decrease the motivation among the students. The best techniques adopted by the teachers are formal lesson planning, discussion, group work, lesson elaboration and team participation (Johnson, 2008). It is evident from the above mentioned table that there are many factors that have strong influence on students motivation to learn. These factors comprised of various teachers side determinants and also students side factors that have strong influence on students motivation to learn. Thus the table shows that active involvement of the students motivates them to learn and attain good grades. Hence $38.7 \%$ respondents strongly agreed that students involvement is the major factor that have direct impact on students motivation to learn. On the other hand $11.3 \%$ respondents denied this standpoint. Despite this the table depicts that $36 \%$ respondents 
strongly agreed that excessive workload on the students reduces their motivation to learn in an adequate way. On the other hand $23.3 \%$ respondents gave a neutral response on this stance. In addition to this the above mentioned table also shows that the internal motivation of the student is long lasting and self directive tool to enhance the students motivation to participate in the learning process and achievement of good grades. Thus 36\% respondents strongly agreed and $2.7 \%$ strongly denied this stance. On the other hand $12 \%$ respondents gave a neutral response on this proposition. When there is a matter of motivation among the students then social and economic incentives plays a vital role in this regard. If the family provides adequate economic incentives and social support to the students then obviously the students are motivated towards the learning process. On the other hand if the students have inadequate family support in terms of emotional and economic incentives then they become non-motivated towards the learning process. It is evident from the above cited table that $47.9 \%$ respondents agreed that adequate incentives provided by the family are the major motivator for the students to learn. In addition to this $12.7 \%$ respondents gave a neutral response on this stance and $7.4 \%$ respondents showed a disagreed response on this issue.

\section{Hypothesis testing:}

H1: Usage of modern teaching methodologies can increase the motivation level of the students towards the process of learning.

H2: Effective classroom environment can increase the motivation level of the students towards the process of learning.

H3: Adequate interaction of teachers with students can increase the motivation level of the students towards the process of learning.

H4: Students own motivation to learn is the major factor that increases the motivation level of the students towards the process of learning.

\subsection{Descriptive Statistics:}

\begin{tabular}{|c|c|c|c|c|c|c|c|c|c|}
\hline \multicolumn{1}{|c|}{ Category } & N & Min & Max & Mean & $\begin{array}{c}\text { Std. } \\
\text { Deviation }\end{array}$ & \multicolumn{2}{|c|}{ Skewness } & \multicolumn{2}{|c|}{ Kurtosis } \\
\cline { 2 - 11 } & Statistic & Statistic & Statistic & Statistic & Statistic & Statistic & $\begin{array}{c}\text { Std. } \\
\text { Error }\end{array}$ & Statistic & $\begin{array}{c}\text { Std. } \\
\text { Error }\end{array}$ \\
\hline Teaching Methodology & 300 & 1.60 & 5.00 & 3.9973 & 0.75689 & -1.101 & 0.198 & 0.836 & 0.394 \\
\hline Classroom environment & 300 & 1.40 & 5.00 & 3.8160 & 0.70111 & -0.914 & 0.198 & 1.311 & 0.394 \\
\hline $\begin{array}{c}\text { Teacher's behavior } \\
\text { interaction with the } \\
\text { student }\end{array}$ & 300 & 1.20 & 5.00 & 3.8867 & 0.85056 & -1.147 & 0.198 & 0.811 & 0.394 \\
\hline
\end{tabular}




\section{Macrothink $\triangle$ Institute ${ }^{\text {tm }}$}

Students' motivation to learn

\section{Discussion of Table No. 5.1:}

Table No. 5.1 demonstrates the hypothesis of the present research. The descriptive statistics show the agreement of the maximum respondents towards a certain variable. The total number of respondents was $\mathrm{N}=300$. The minimum and the maximum value for the descriptive statistics show all the data has been entered in a correct manner. The mean value which is more than 3 shows maximum respondents agreed on this particular statement. As the descriptive analysis shows that the mean value for first hypothesis [H1: Usage of modern teaching methodologies can increase the motivation level of the students towards the process of learning] is 3.9973. On the other hand the table shows that the mean value for the second hypothesis [H2: Effective classroom environment can increase the motivation level of the students towards the process of learning] is 3.8160 while for the third hypothesis [H3: Adequate interaction of teachers with students can increase the motivation level of the students towards the process of learning] this value is 3.8867 and for last hypothesis [H4: Students own motivation to learn is the major factor that increases the motivation level of the students towards the process of learning] this value becomes 4.0147. The values of skewness and kurtosis from the table of descriptive statistics are used to find out the normality of data. From the above mentioned table the researcher find out that the value of skeweness for all the variables lies between the ideal range. This ideal range was -1 to +1 . On the other hand the value of remaining 2 variables lies in a acceptable range. This acceptable range was -2 to +2 . The above mentioned table also discussed that these values must be positive that shows the normality of the data.

\subsection{Pearson Correlation:}

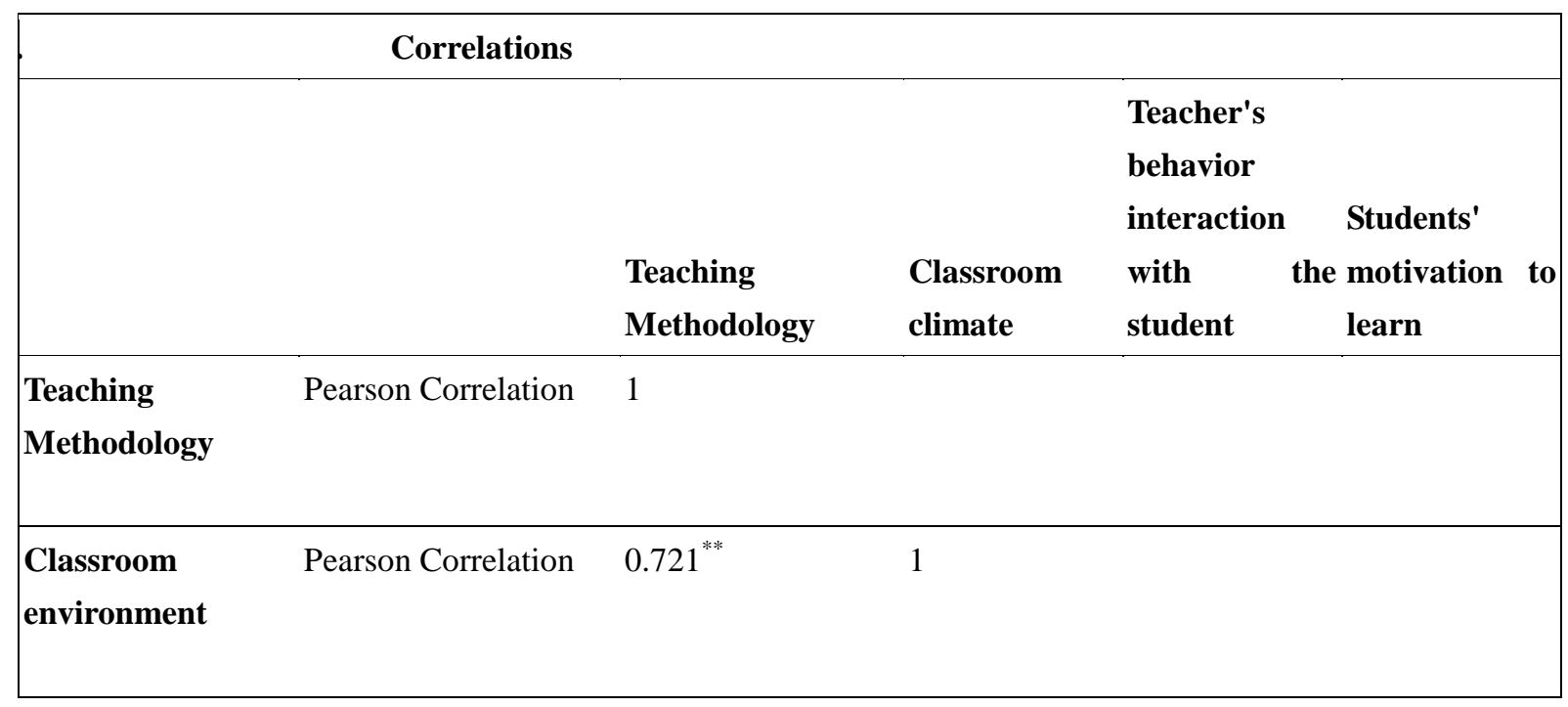




\begin{tabular}{|l|lll|}
\hline \hline $\begin{array}{l}\text { Teacher's } \\
\text { behavior } \\
\text { interaction } \\
\text { the student }\end{array}$ with & $0.742^{* *}$ & 1 \\
\hline $\begin{array}{l}\text { Students' } \\
\text { motivation } \\
\text { learn }\end{array}$ to Pearson Correlation $0.639^{* *}$ & $0.730^{* *}$ & $0.639^{* *}$ & 1 \\
\hline & & & \\
\hline$* *$ Correlation is significant at the 0.01 level (2-tailed). \\
\hline
\end{tabular}

\section{Discussion of Table No. 5.2:}

Table No. 5.2 reveals that the correlation analysis demonstrated the relationship between the dependant and independent variables. The independent variables are teaching methodology, classroom environment, teachers interaction with the students and students own motivation to engage in the learning process. While the dependant variable is motivation to learn. From table no. 2 (b) suggests that the Pearson coefficient relationship (among the dependant and independent variables) is significant. Moreover for all the variables the significant value $(\mathrm{p})$ is less than $0.05(\mathrm{p}<0.05)$ which means that null hypothesis is rejected. On the other hand the results are significant and supportive for the alternate hypothesis. The entire hypothesis is accepted at the $0.01(99.9 \%)$ level of significance.

H1: Usage of modern teaching methodologies can increase the motivation level of the students towards the process of learning.

[Alternate hypothesis is accepted at 0.01 level of significance].

H2: Effective classroom environment can increase the motivation level of the students towards the process of learning.

[Alternate hypothesis is accepted at 0.01 level of significance].

H3: Adequate interaction of teachers with students can increase the students motivation level of the students towards the process of learning.

[Alternate hypothesis is accepted at 0.01 level of significance].

H4: Students own motivation to learn is the major factor that increases the motivation level of the students towards the process of learning.

[Alternate hypothesis is accepted at 0.01 level of significance]. 


\subsection{One-Way ANOVA:}

\begin{tabular}{|c|c|c|c|c|c|}
\hline ANOVA $^{b}$ & & & & & \\
\hline Model & Sum of Squares & df & Mean Square & $\mathbf{F}$ & Sig. \\
\hline Regression & 48.474 & 3 & 16.158 & 63.530 & $.000^{\mathrm{a}}$ \\
\hline Residual & 37.133 & 146 & 0.254 & & \\
\hline Total & 85.608 & 149 & & & \\
\hline $\begin{array}{l}\text { a. Predictors } \\
\text { environment }\end{array}$ & Teacher's behavic & nterac & $\mathrm{h}$ the student, $\mathrm{T}$ & ing Metl & gy, Cl \\
\hline
\end{tabular}

\section{Discussion of Table No. 5.3:}

Table No. 5.3 shows ANOVA table that illustrates the difference among more than two mean values. If $p>0.05$ then the researcher must accept the null hypothesis (H0) but as the data was normal and value of $p$ was $(p<0.05)$ therefore the researcher accept alternate hypothesis (H1) which shows that the data is not normal and there is variance among the variables. As the data indicates that ANOVA value is less than 0.05 therefore Null hypothesis is rejected and alternate hypothesis is accepted. The independent variables are teacher's behavior and interaction with the student, teaching methodology used by the teachers in classroom and classroom environment. On the other hand the dependant variable is students motivation to learn. As there is the difference among the three means therefore $p$ value of ANOVA is $p=0.000$. It means that all these variables have difference in increasing the motivation level of the students towards the process of learning.

\subsection{Reliability Statistics:}

\begin{tabular}{|l|c|c|}
\hline Description & Cronbach's Alpha & N \\
\hline Teaching Methodology & 0.743 & 300 \\
\hline Classroom Climate & 0.655 & 300 \\
\hline Teacher's behavior with the student & 0.855 & 300 \\
\hline Students' motivation to learn & 0.780 & 300 \\
\hline
\end{tabular}




\section{Discussion of Table no. 5.4:}

2013, Vol. 3, No. 2

Table No. 5.4 shows that the reliability analysis is used to make sure the inter item reliability for all the variables. In this, the value of Cronbach's Alpha must be greater than 0.6. The above mentioned results reveal that those required values were greater than 0.6 for all independent and dependent variables which means all the variable are reliable. $\mathrm{N}$ shows that the sample size is $\mathrm{N}=300$.

H1: Usage of modern teaching methodologies can increase the motivation level of the students towards the process of learning. [The value for the Cronbach's Alpha is 0.743 for hypothesis No. 1 which shows that null hypothesis is rejected and alternate hypothesis is accepted for $\mathrm{N}=300$ )

H2: Effective classroom environment can increase the motivation level of the students towards the process of learning. [The value for the Cronbach's Alpha is 0.655 for hypothesis No. 2 which shows that null hypothesis is rejected and alternate hypothesis is accepted for $\mathrm{N}=300)$

H3: Adequate interaction of teachers with students can increase the motivation level of the students towards the process of learning. [The value for the Cronbach's Alpha is 0.855 for hypothesis No. 3 which shows that null hypothesis is rejected and alternate hypothesis is accepted for $\mathrm{N}=300$ )

H4: Students own motivation to learn is the major factor that increases the motivation level of the students towards the process of learning. [The value for the Cronbach's Alpha is 0.780 for hypothesis No. 4 which shows that null hypothesis is rejected and alternate hypothesis is accepted for $\mathrm{N}=300$ )

\section{Conclusion and Recommendations:}

After revering the analysis the researcher concluded that motivation is the key factor and the noteworthy medium that can increase the conceptualization and performance level of the student. There are many factors that have momentous influence on increasing or decreasing the level of motivation of the students towards their process of learning. These factors include class size, attitude of the teachers towards their students and internal motivation of the student. On the other hand non-verbal encouragement of the teachers to their students, establishment of cooperative learning environment and adequate incentives given to the students have an imperative influence on increasing the motivation level of the students towards their process of learning. When the teachers uses obsolete teaching methodologies and put excessive workload on the students then the motivation level of the students decreases. Students motivation towards learning process helps them to acquire good academic grades. Not only teachers but parents and school administration are the major stakeholders that have the momentous impact on the motivational level of the students towards their learning process. The researcher suggested the subsequent recommendations about this research: 
1. Teachers must assign different tasks to the students in order to increase their academic grades but these tasks must be according to the abilities of the students.

2. Teachers must assign tasks to the students that can increase their motivation and conceptualization about the particular course content.

3. Classroom environment must support the assessment criterion for the purpose of students evaluation.

4. Teachers must enhance the learning goals among the students by emphasizing on their positive feedback.

5. Teachers must motivate the students by establishing environment of affection, coordination and participation.

6. Teachers should motivate the students to conceptualize their lectures in an adequate manner.

7. Not only teachers but parents should also participate for removing the educational constraints of their children. Students need guidance and motivation in order to enhance their educational performance.

8. When students are given opportunity to share their own point of view then they will find some intellectual relief and motivation to work.

9. Appreciation, encouragement and motivation together increase the educational attainment of the students.

10. There are some important ways through which a teacher can establish a learning environment in a class. These ways include 1) Cooperative learning environment in classroom settings 2) Non-biased behavior of the teacher and 3) Usage of effective and modern teaching methodologies by the students. The only way when the students are motivated to achieve good academic grades in the school is when they realize that their teachers are responsive and satisfied with their involvement in studies

11. Teachers should not expect the unrealistic goals from the students.

12. Teachers must have deep understanding of the subject and they should assist the students to understand their talents so that the students can be motivated towards good academic achievements.

13. Instructors should focus on using discussion as an effective teaching methodology because it can increase the motivation of the students towards learning process. In discussion method the students exchange ideas with the teachers and among themselves. In discussion the learners will be engaged in thinking, reasoning and opinion making.

14. Teachers should induce group work as an effective teaching methodology to increase the motivation of the students about the particular course content.

\section{References:}

1. Afzal, H., I. Ali, M. A. Khan and K. Hamid. 2004. "A Study of University Students Motivation and its Relationship with their Academic Performance." Journal of Business and Management, Vol. 5, No. 4, pp. 80-88.

2. Ali, Z., I. A. Tatlah and M. Saeed. 2011. "Motivation and Students Behavior: A Tertiary Level Study." International Journal of Psychology and Counseling, Vol. 3, No. 2, pp. 29-32. 
3. Atta, M. A. and A. Jamil. 2012. "Effects of Motivation and Parental Influences on Educational Attainments of Students at Secondary Level." Academic Research International, Vol. 2, No. 3, pp. 427-431.

4. Bielaczyc, K. 2003. "Learning Communities." Encyclopedia of Education ( $2^{\text {nd }}$ Edition) pp.1162-1163. New York: Macmillian.

5. Boo, H., M. Ng, J. Chew, C. Lee, A. Ambrose-Yeoh, and V. Rozario. 2001. "Challenges of Integrating Cooperative Learning in Primary Science Classrooms. Paper presented at the Joint Conference of Australian Association for Research in Education (AARE) and Singapore Educational Research Association (SERA)." Fremantle.

6. Bridges, D. 1990. "The Character of Discussion: A Focus on Students." Teaching and Learning through Discussion, Springfield, IL. Thomas.

7. Brookfield, S. 1990. "The Skillful Teacher: On Technique, Trust and Responsiveness in the Classroom." San Francisco.

8. Broussard, S. C. and M. E. Garrison. 2004. "The Relationship between Classroom Motivation and Academic Achievement in Elementary School Aged Children." Family and Consumer Research Journal, Vol. 33, No. 2, pp. 106-120.

9. Condry, J. 1987. "Enhancing Motivation: A Social Developmental Perspective." Advances in Motivation and Achievement, Vol. 5.

10. Dart, B. 1994. "Measuring Constructivist Learning Environments in Tertiary Education." A Paper Presented at the Annual Conference of the Australian Association for Research in Education, Newcastle.

11. Dean, R. J. and L. Dagostino. 2007. "Motivational Factors affecting Advanced Literacy Learning of Community College Students." Community College Journal of Research and Practice, Vol. 31, pp. 149-161.

12. Deci, E. L., R. Koester and R. M. Ryan. 1999. "A Metanalytical Review of Experiments Examining the Effects of Extrinsic Rewards on Intrinsic Motivation." Psychological Bulletin, Vol. 125, No. 6, pp. 627-668.

13. Dickinson, A. and B. Balleine. 2002. "The Role of Learning in the Operation of Motivational Systems." Stevens Handbook, pp. 497-534.

14. Dillon, J. T. 1994. "Using Discussions in Classrooms." Buckingham, Philadelphia: Open University Press.

15. Eley, M. G. 2006. "Teachers' Conceptions of Teaching, and the Making of Specific Decisions in Planning to Teach.” Higher Education, Vol. 51, No. 2, pp. 191-214.

16. Evertson, C., E. Emner, B. Clemets and M. Worsham. 2000. "Classroom Management for Elementary Teachers." Boston: Allyn and Bacon.

17. Gottfried, A. E., J. S. Fleming and A. W. Gottfried. 2001. "Continuity of Academic Intrinsic Motivation from Childhood through Late Adolescent: A Longitudinal Study." Journal of Educational Psychology, Vol. 93, No. 1, pp. 1-14.

18. Hidi, S. and J. M. Harackiewicz. 2000. "Motivating the Academically Unmotivating: A Critical Issue for $21^{\text {st }}$ Century." Review of Educational Research, Vol. 70, No. 2, pp. 151-179. 


\section{Macrothink}

19. Higbee, J. C. 1996. “Ability, Preparation and Motivation." Research and Teaching in Developmental Education. pp. 93.

20. Johnson, L. A. 2008. "Relationship of Institutional Methods to Students Engagement in Two Public High Schools.” American Secondary Education, Vol. 36, pp. 69-87.

21. Killen, R. 2003. "Effective Teaching Strategies: Lessons from Research and Practice." Third Edition. Ligare Book Printers, Australia.

22. Murdock, T. and A. Miller. 2003. "Teachers as a Source of Middle School Students Motivational Identity: Variable Centered and Person Centered Analytical Approaches.” The Elementary School Journal, Vol. 103, No. 4, pp. 383-399.

23. Murphy, P. K. 2004. "The Good Teacher and Good Teaching: Comparing Beliefs of Second-Grade Students, Pre-service Teachers, and In-Service Teachers." The Journal of Experimental Education, Vol. 72, No. 2, pp. 69-92.

24. Nilsen, H. 2009. "Influence on Student Academic Behavior through Motivation, Self-Efficacy and Value-Expectation." Issues in Informing Science and Information Technology, Vol. 6, pp. 545-556.

25. Nye, B. 2004. "How Large Are Teacher Effects?" Educational Evaluation and Policy Analysis, Vol. 26, No. 3, pp. 237-257.

26. Quinn, T. and T. Eckerson. 2010. "Motivating Students to Read with Collaborative Reading Quizzes.” English Journal, Vol. 100, No. 1, pp. 89-91.

27. Sattar, T. 2012. "A Sociological Analysis of Education as a Prerequisite for the Process of Development: A Case of Southern Punjab (Pakistan)." International Journal of Learning and Development, Vol. 2, No. 2, pp. 112-132.

28. Sattar, T. 2012. "Determinants and Implications of Weak Teachers Performance in Education Sector: A Case of Affiliated Schools of Board of Intermediate and Secondary Education, Multan Division (Pakistan)." International Journal of Accounting and Financial Reporting, Vol. 2, No. 1, pp. 116-133.

29. Stipek, D. J. 1996. "Motivation and Instruction." Handbook of Educational Psychology, New York, USA.

30. Sutherland, K. S. 2005. "The Relationship Between Teacher and Student Behavior in Classrooms for Students with Emotional and Behavioral Disorders." Journal of Child and Family Studies, Vol. 14, No. 1, pp. 1-14.

31. Tanveer, M. A., M. F. Shabbir, M. Ammar, S. I. Polla and H. D. Aslam. 2012. "Influence of Teachers in Students Motivation in Management Sciences Studies." American Journal of Scientific Research, Vol. 67, pp. 76-87.

32. Theobald, M. 2006. "Increasing Students Motivation: Strategies for Middle and High School Teachers." Thousand Oaks, CA: Corwin Press.

33. Thrash, T. and A. Elliot. 2001. "Delivering and Integrating Achievement Motive and Goal Constructs." Trends and Prospects in Motivational Research, Kluwer.

34. Tigelaar, D. E. H. 2004. "The Development and Validation of a Framework for Teaching Competencies in Higher Education." Higher Education, Vol. 48, No. 2, pp. 253-268. 
35. Whiting, M. J., J. Liu and A. P. Rovai. 2008. "Distinguishing sense of Community and Motivational Characteristics between Online and Traditional Colleges Students." The Quarterly Review of Distance Education, Vol. 9, No. 3, pp. 285-295.

36. Wigfield, A. and E. Eccler. 2000. "Expectancy Value Theory of Achievement Motivation." Contemporary Educational Psychology, Vol. 25, pp. 68-81.

37. Winkel, B. J. 1999. "Formative Assessment During Complex, Problem Solving Group Work in Class." Assessment Practices in Undergraduate Mathematics. Washington DC. USA.

38. Wiseman, D. and G. Hunt. 2001. "Best Practice in Motivation and Management in this Classroom." Springfield: Charbs, C. Thomas Publisher, Limited.

39. Wong, H. K. and R. T. Wong. 1998. "How to be an Effective Teacher: The First Days of School." Mountain View: Wong Publications.

40. Young, A, J. 1977. "Classroom Climate and Class Success: A Case Study at the University Level.” The Journal of Educational Research, Vol. 70, No. 5, pp. 252-257. 